\title{
DIET COMPOSITION OF RED BANDFISH, CEPOLA MACROPHTHALMA (ACTINOPTERY- GII: PERCIFORMES: CEPOLIDAE), FROM THE AEGEAN SEA OF TURKEY
}

\author{
Tuncay Murat SEVER and Dilek İLHAN* \\ Ege University, Faculty of Fisheries, 35100, Bornova-İzmir, Turkey
}

Sever T.M., İlhan D. 2016. Diet composition of red bandfish, Cepola macrophthalma (Actinopterygii: Perciformes: Cepolidae), from the Aegean Sea of Turkey. Acta Ichthyol. Piscat. 46 (3): 211-224.

\begin{abstract}
Background. The red bandfish, Cepola macrophthalma (Linnaeus, 1758), is a benthic fish usually not exceeding $450 \mathrm{~cm}$ in length. It occurs in the eastern Atlantic from the British Isles to the north of Senegal and is also common throughout the Mediterranean Sea. The red bandfish has no commercial value and is often represented in the discarded catch. The knowledge of the feeding ecology, of non-commercial as well as commercial species, is essential for implementing a multispecies approach to fishery management. Studies on red bandfish feeding biology have been rather scarce and the majority of them lacked taxonomical approach. The presently reported study constitutes the first report on the diet of Cepola macrophthalma from two bays on the Turkish coast.

Material and methods. The study was based on the specimens of Cepola macrophthalma collected in İzmir Bay and Sığacık Bay from May 2005 to June 2006. The following basic parameters were calculated, based on the data collected during the analysis of red bandfish diet: relative number of food items in the gut content, frequency of occurrence, and relative weight of total gut content. Principal food items were determined using the index of relative importance (\%IRI). The differences in the diet composition were tested for length groups and seasons by using the Bray-Curtis similarity index for both areas studied.

Results. A total of 380 stomachs were examined in two bays. According to the analyses a total of 18 different prey species belonging to nine major systematic groups were found, i.e., Anthomedusae, Siphonophora, Polychaeta, Crustacea, Mollusca, Chaetognatha, Appendicularia, Thaliacea, and Actinopterygii. Concerning overall diet composition, crustaceans (especially copepods) were the most important prey in terms of $\%$ IRI, $\% N, \% F$, and $\% W$ in all seasons. In this study, a total of 80 taxa were found and identified. According to the Bray-Curtis similarity index, the diet of the red bandfish was similar within all seasons for both areas.

Conclusion. Stomach content analysis of red bandfish showed that it is a zooplanktophagous species. In addition to bottom species it feeds also on pelagic organisms. This fact indicates ontogenetically based food preferences of the species.
\end{abstract}

Keywords: stomach content, feeding ecology, index of relative importance, zooplanktophage, İzmir Bay

\section{INTRODUCTION}

The red bandfish, Cepola macrophthalma (Linnaeus, 1758), is a zooplanktophagous benthic species found solitary or in small groups at depths ranging from 10 to $450 \mathrm{~m}$, with an "optimal depth window" between 60 and $120 \mathrm{~m}$ (Stergiou 1993). It occurs in both temperate and subtropical waters and is known to be distributed in the eastern Atlantic from the British Isles to the north of Senegal (Bauchot 1987). It is also common throughout the Mediterranean Sea, as well as in Turkish seas, but not in the Black Sea (Tortonese 1986, Bauchot 1987). The red bandfish has economical importance in Spain and Italy (Tortonese 1986, Bauchot 1987), but no commercial value in Turkey (Düzbastılar 2014).
Although biological aspects of the red bandfish have been studied by several authors (Atkinson 1976, Martín and Sabatés 1991, Stergiou et al. 1992, 1996, Stergiou 1993, 1999, Stergiou and Papaconstantinou 1993, Vallisneri et al. 2006, Dulčić et al. 2008, Giacalone et al. 2010) in the Mediterranean Sea, a few of them are related to the feeding of red bandfish. In the above-mentioned studies prey items were generally not evaluated in relation to the exact specific identity or the sampling season. Even though the species is distributed in all Turkish seas except the Black Sea, the relevant studies were scarce and there have only been two reports on its age and growth properties (Kaya et al. 2001, Leblebici unpublished ${ }^{* *}$ ).

\footnotetext{
* Correspondence: Assoc. Prof. Dr. Dilek İlhan, Ege Üniversitesi, Su Ürünleri Fakültesi, Bornova, İzmir, Türkiye, phone: +90 232 3115341 ; fax: +90 232 3883685 , e-mail: (Di) d.uckun.ilhan@gmail.com, (TMS) t.murat.sever@ege.edu.tr.

** Leblebici S. 2007. İzmir Körfezi’nde Yaşayan Kurdela Balığı, Cepola macrophthalma (Linnaeus, 1758) Türünün Biyolojik Özelliklerinin Araştırılması. [Investigations on the biological properties of red bandfish Cepola macrophthalma (Linnaeus, 1758) in İzmir Bay.] PhD Thesis. Ege University, Izmir, Turkey. [In Turkish.]
} 
The purpose of the presently reported study was to improve the knowledge on the feeding habits of the red bandfish by analysing the qualitative and quantitative variations of the food items in the stomach contents according to length groups and according to seasons in two bays of the Aegean Sea.

\section{MATERIAL AND METHODS}

Specimens of the red bandfish, Cepola macrophthalma (total lengths ranging between 11 and $42.2 \mathrm{~cm}$ ), were collected by trawl in the İzmir Bay and Sığacik Bay, Turkish Aegean Sea from May 2005 to June 2006 (Fig. 1).

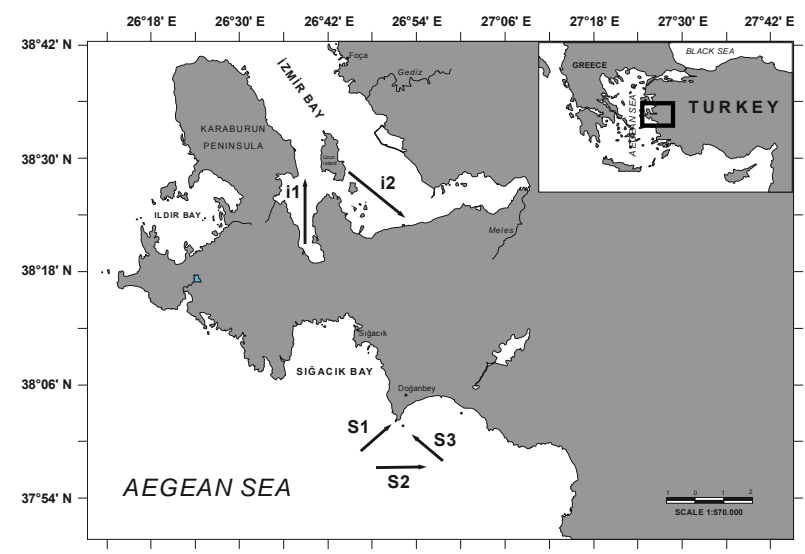

Fig. 1. Research area and trawling locations

The samples were collected seasonally by a research vessel-R/V Egesüf ( $27 \mathrm{~m}$ length, $373 \mathrm{kw})$ in İzmir Bay and by a commercial trawler-F/V Hapuloğlu (23 $\mathrm{m}$ length, $410 \mathrm{kw})$ in Siğacık Bay. The sampling depth ranged between 45 and $70 \mathrm{~m}$ in İzmir Bay, and 145-296 $\mathrm{m}$ in Sığacık Bay. The fish stomachs were removed immediately after capture and were stored in $4 \%$ buffered formalin solution until the contents were analysed. In the laboratory the stomach contents were assigned to groupor species level with a SZX7 Olympus stereo microscope. The identification of digested copepods was done from body part by following the methods of Rose (1933) and Brodskii (1967). Once counted, the individuals of the same species were weighed together (wet weight to the nearest $0.0001 \mathrm{~g}$ ) after excess moisture was removed by blotting prey items on tissue paper.

For a quantitative description of the diet, Hyslop (1980) equations were used; relative number of total gut content $(\% N)$, frequency of occurrence $(\% F)$, and relative weight of total gut content $(\% W)$. Main food items were determined using the index of relative importance (IRI) (Pinkas et al.1971):

$$
\text { IRI }=\% F \times(\% N+\% W)
$$

The index of relative importance (IRI) was calculated and expressed as a percentage:

$$
\mathrm{IRI} \%=100 \times \mathrm{IRI} \cdot\left(\sum \mathrm{IRI}\right)^{-1}
$$

\%IRI was computed in order to determine ratios of food groups in the stomach to overall food groups. Subsequently, food items were grouped into categories of preference using the method proposed by Morato-Gomes (unpublished ${ }^{*}$ ). The categories were defined as follows: IRI $\geq 30 \times(0.15 \times \Sigma \% F) \ldots \ldots .$. main important prey (MIP) $30 \times(0.15 \times \Sigma \% \mathrm{~F})>\mathrm{IRI}>10 \times(0.05 \times \Sigma \% \mathrm{~F})$ ..secondary prey (SP)

$\mathrm{IRI} \leq 10 \times(0.05 \times \Sigma \% \mathrm{~F})$ occasional prey (OP)

Seasonal differences in the diet composition for each bay were determined by the Bray-Curtis similarity index, using percentage numerical data (Washington 1984).

\section{RESULTS}

A total of 380 stomachs of red bandfish, Cepola macrophthalma, were examined, including 180 from İzmir Bay and 200 from Siğacık Bay. Only 7 stomachs $(1.84 \%)$-all of them collected in winter-were empty. According to the analyses a total of 18 different prey species was found belonging to the nine major systematic groups, Anthomedusae, Siphonophora, Polychaeta, Crustacea, Mollusca, Chaetognatha, Appendicularia, Thaliacea, and Actinopterygii. Pelagic copepods (Copepoda) were found to be most important prey group (MIP) in the diet for all length groups and seasons in each bay. Secondary prey groups (SP) were determined as decapod larvae, Appendicularia, Cladocera, Cirripedia larvae, Chaetognatha, and Bivalvia and it has been found that the sequence of their abundance changed by seasons and length groups, whereas Siphonophora, Isopoda, Mysidacea, Amphipoda, and Ostracoda were rare and rated as occasional prey groups (OP) (Tables 1-5).

Considering the overall diet composition, crustaceans (especially copepods) were the most important prey items in terms of $\%$ IRI, $\% N, \% F$, and $\% W$ in all seasons and length groups for each bay The remaining portion of the diet was shared by decapod larvae, Chaetognatha, Appendicularia, Cladocera, Cirripedia larvae, Brachyura larvae, Ostracoda, Mysidacea, Bivalvia, Anthomedusae, Siphonophora, fish larvae and eggs, Thaliacea, Polychaeta, Amphipoda, Isopoda, and Gastropoda (Tables 1-4). In the presently reported study, covering all seasons, a total of 80 taxa were determined (Tables 1 and 2). There were 69 taxa in the fish from İzmir Bay 69 and 67-from Siğacık Bay.

The diet of red bandfish for all seasons was made up mainly of pelagic copepods for both bays as the main food item (Tables 1 and 2). The abundance of pelagic copepod species changed by seasons. In İzmir Bay, the dominant food items were: Oncaea media, Corycaeus typicus, Acartia clausi, and Clausocalanus arcuicornis (in spring); Centropages typicus and Ditrichocorycaeus brehmi (in summer); Ditrichocorycaeus brehmi, Temora stylifera, Oncaea media, and Euterpina acutifrons (in autumn); and Temora stylifera, and Paracalanus parvus (in winter). In Siğacık Bay, the dominant food items were: Corycaeus typicus and Oncaea media (in spring); Centropages typicus, Ditrichocorycaeus brehmi, Corycaeus giesbrechti (in summer); Ditrichocorycaeus brehmi, Paracalanus

* Morato-Gomes T. 1995. Ecologia alimentar de Serranus atricauda (Günther, 1874) dos Açores. „Licenciatura” Thesis, Universidade do Algarve, Faro, Portugal. 


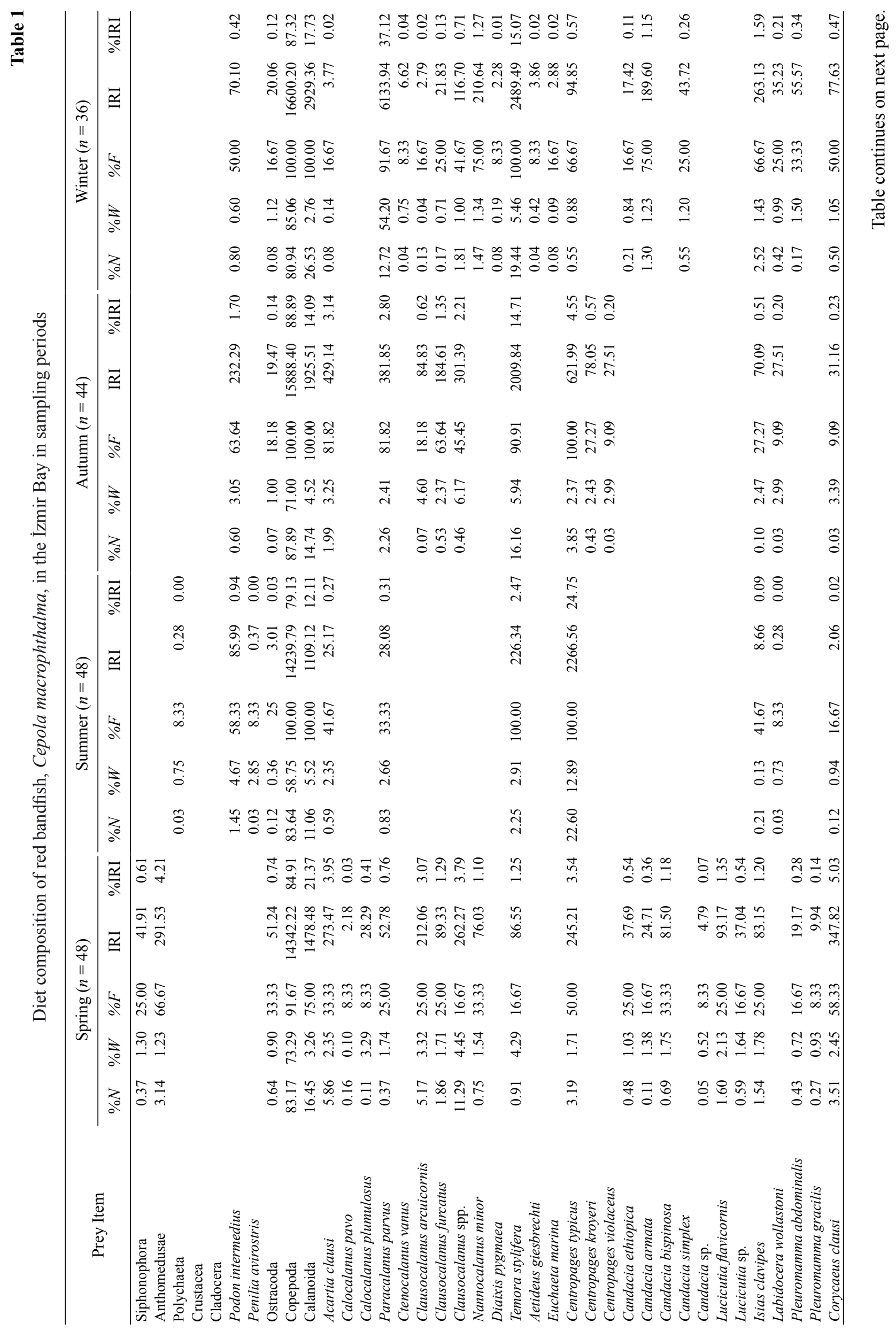




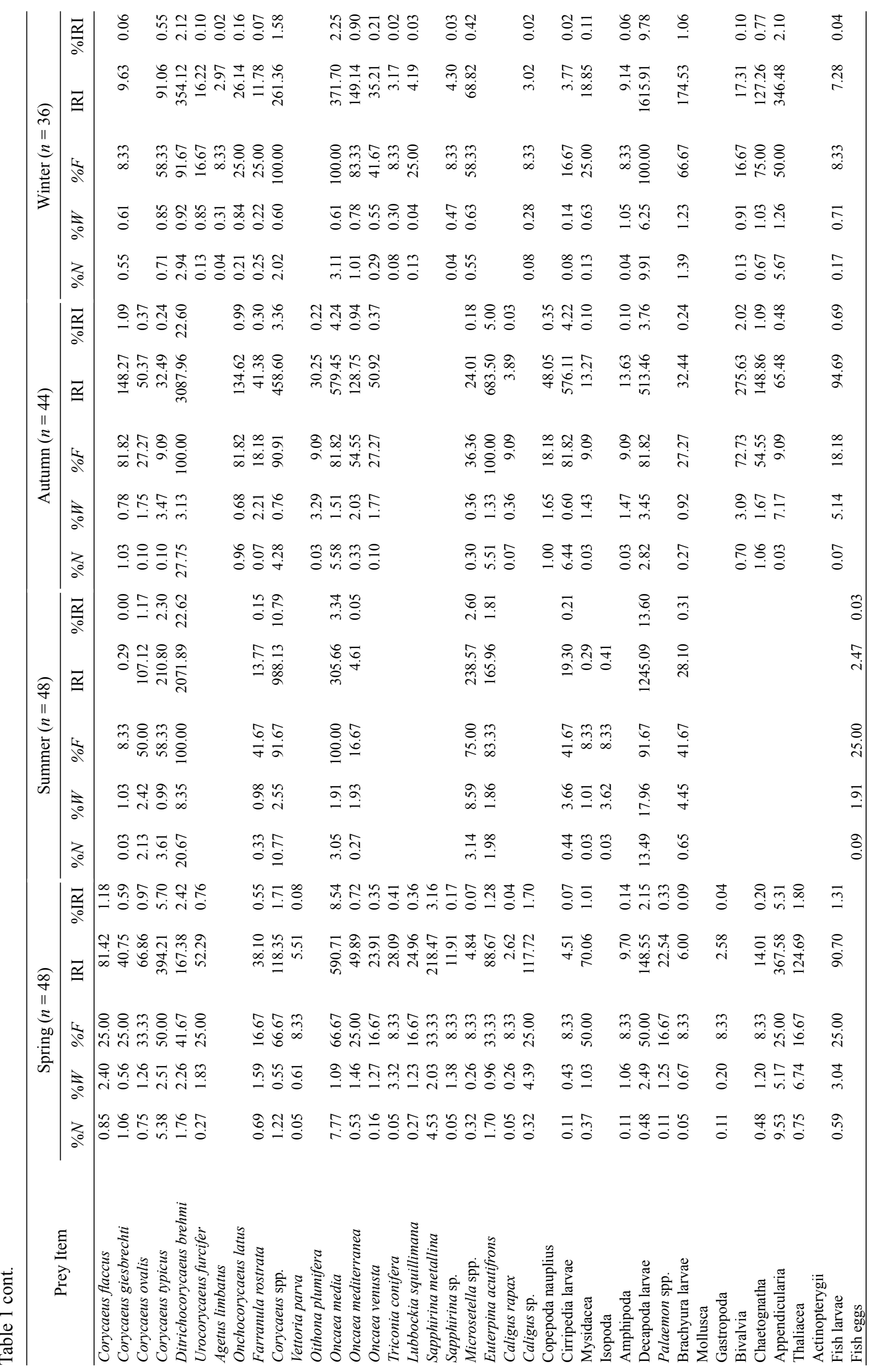




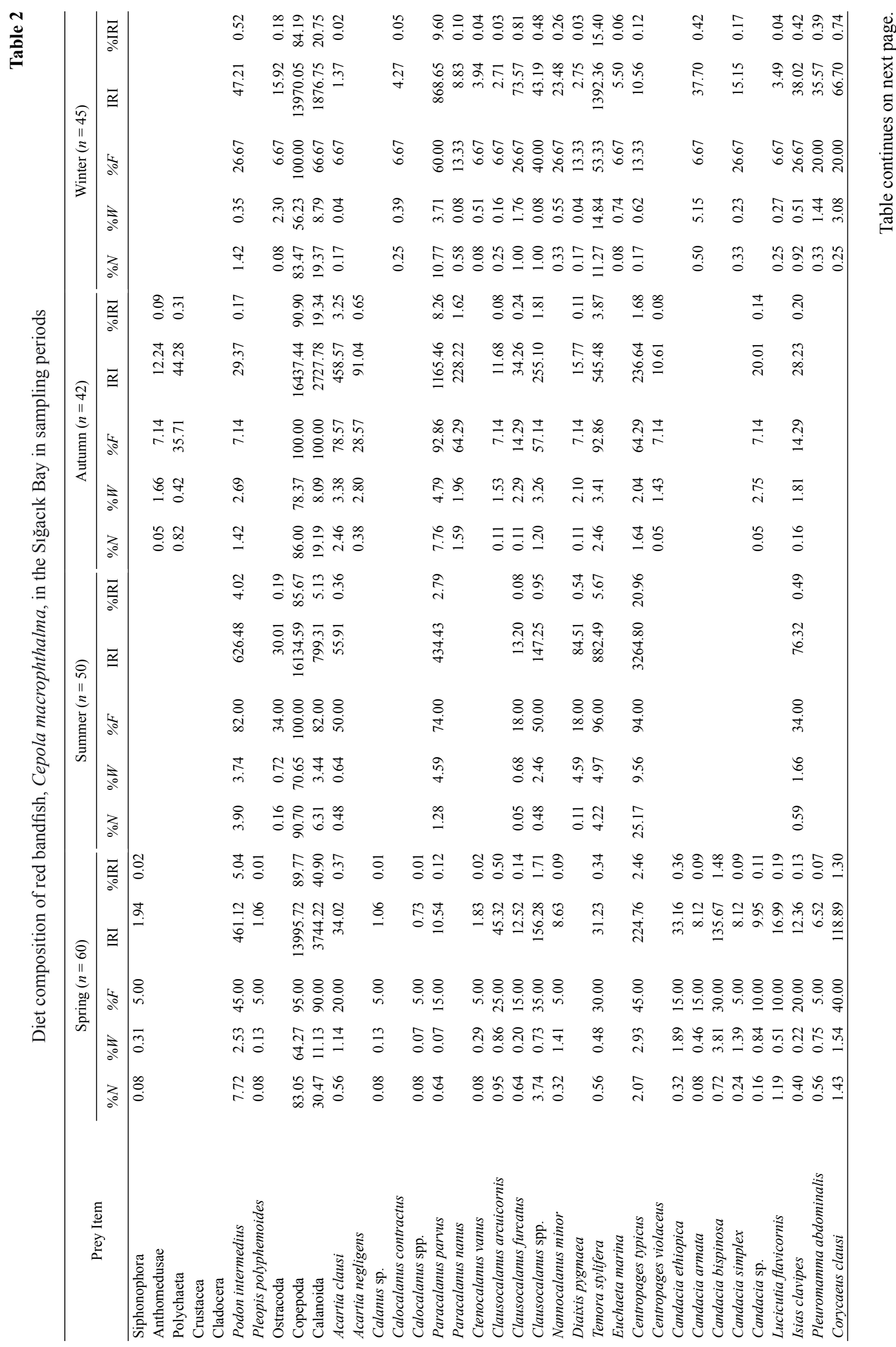




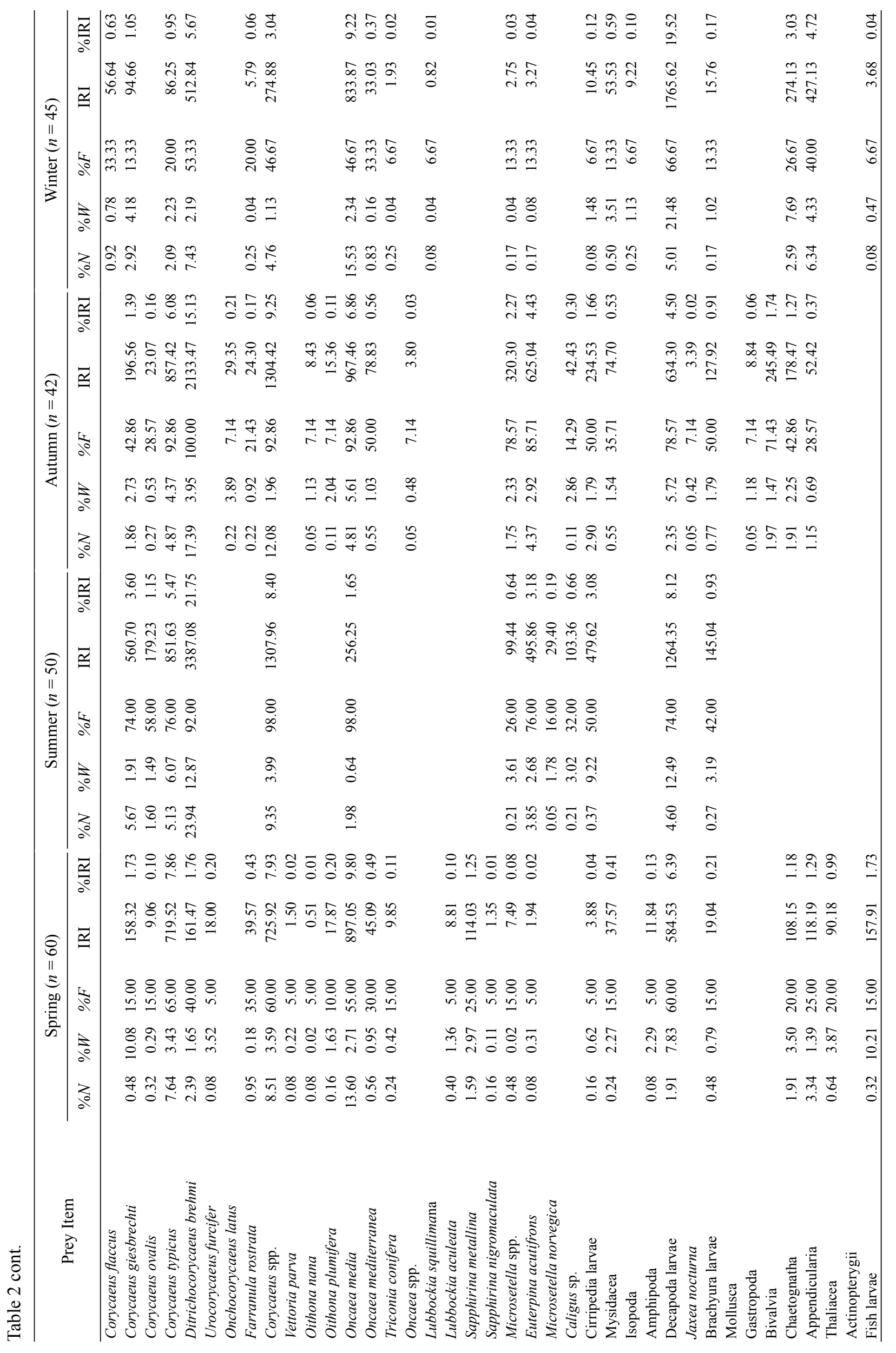




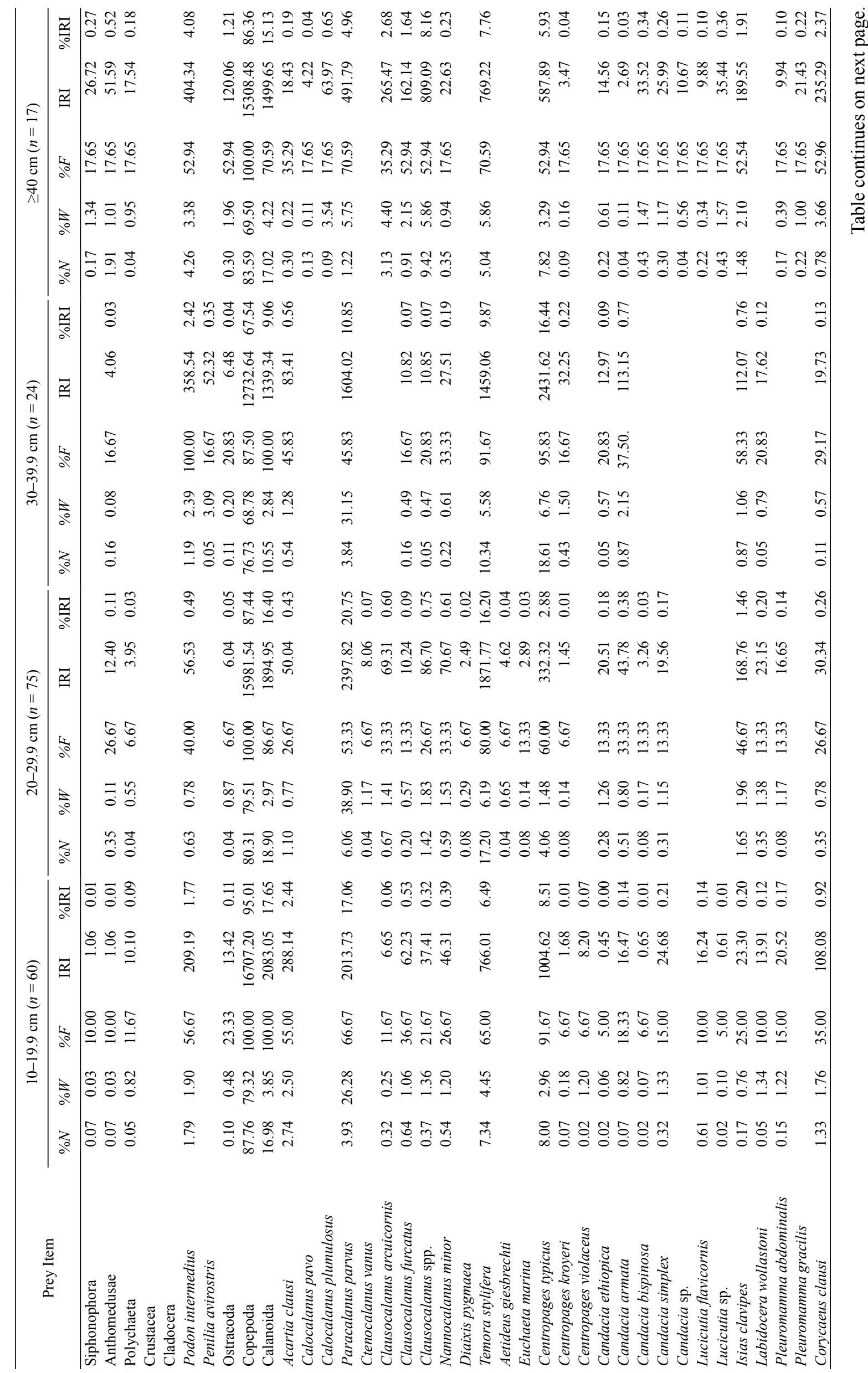




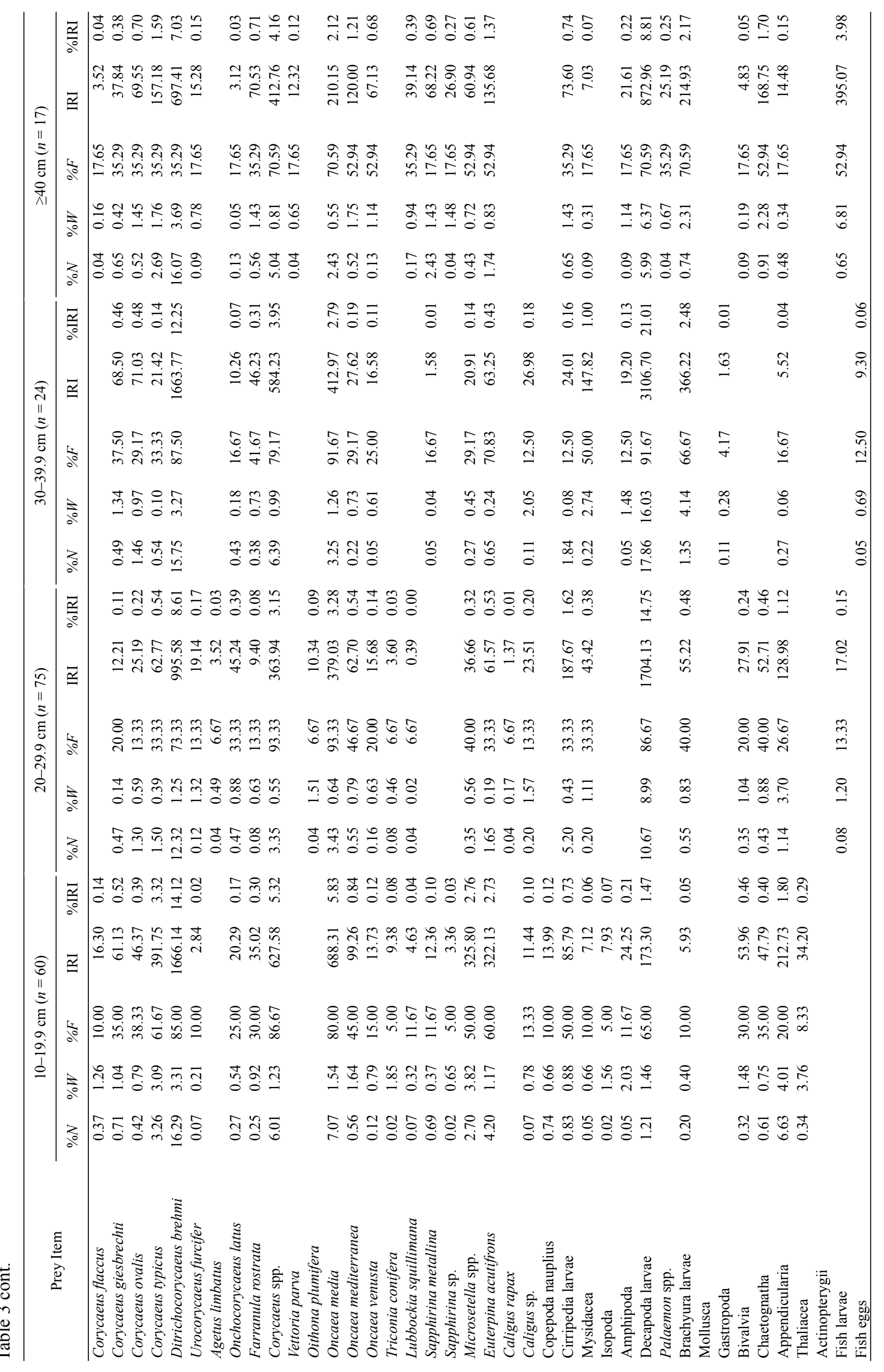









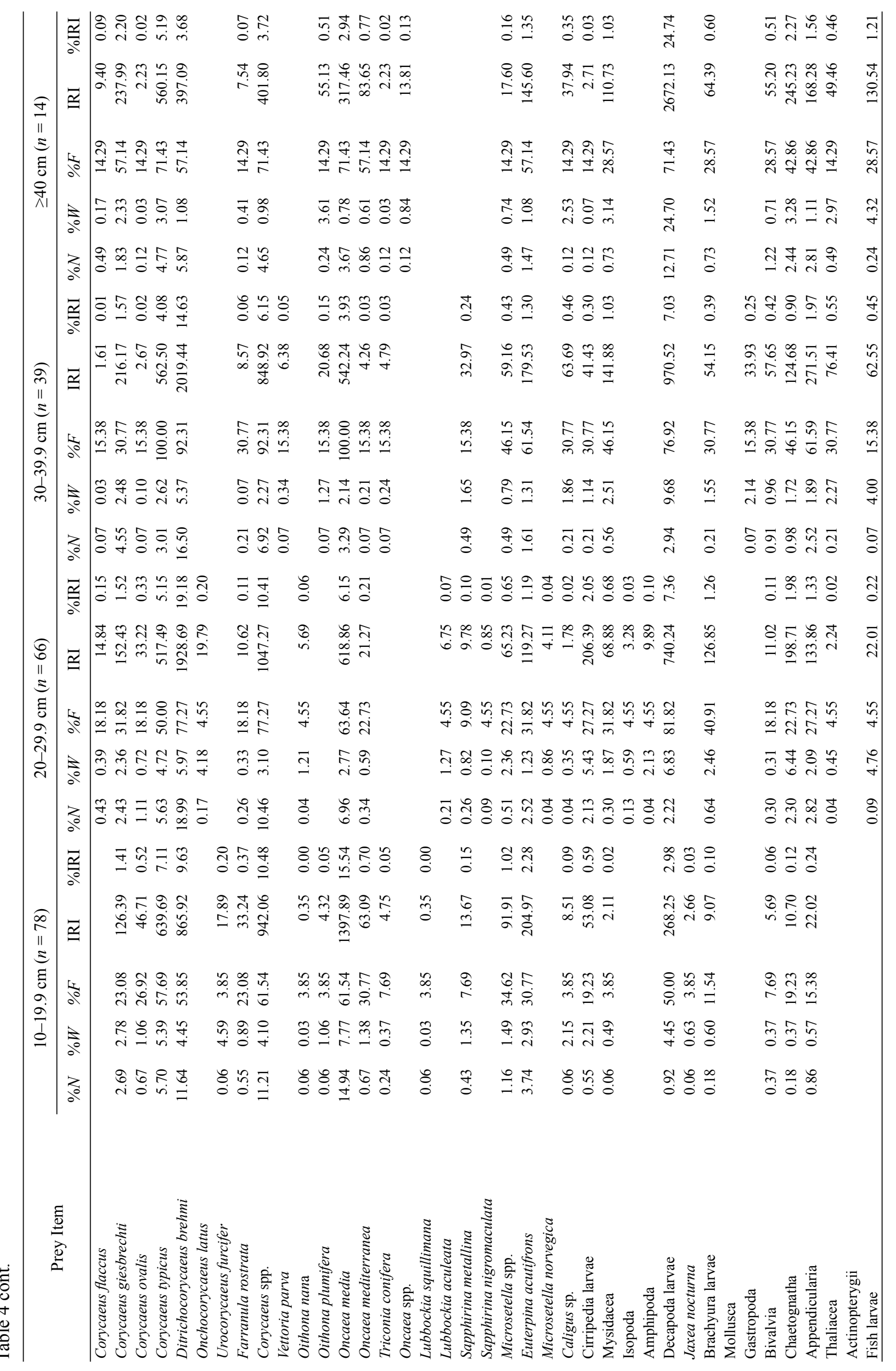




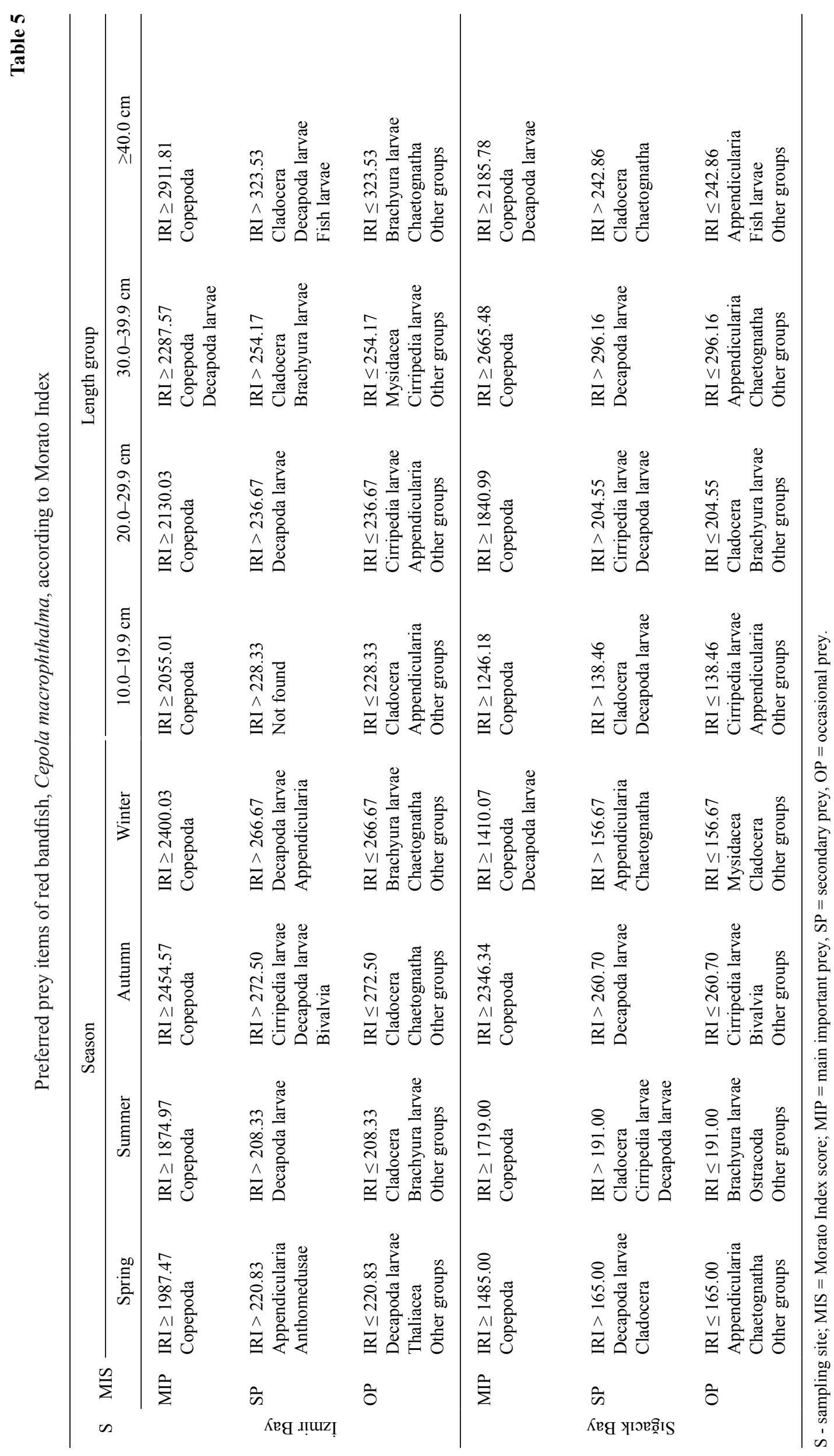


parvus (in autumn); and Oncaea media, Temora stylifera, Paracalanus parvus, and Ditrichocorycaeus brehmi (in winter). In each bay, the diet of red bandfish for all length groups consisted of pelagic copepods as the main food item. However, the number of the decapods and teleost larvae, which are bigger prey items compared with Copepods, increased slightly along with the increasing size of the bandfish increased (Tables 3 and 4).

According to the Bray-Curtis similarity index, the diet composition of the red bandfish was similar for seasons in each bay. The similarities were found as $78.89 \%$ in summer, $75.93 \%$ in autumn, $75.02 \%$ in winter, and $70.91 \%$ in spring (Fig. 2).



Fig. 2. Dendogram showing seasonal similarities in stomach contents of Cepola macrophthalma, based on the BrayCurtis index (abbreviations: İ (prefix) = İzmir Bay, S (prefix) = Sığacık Bay; Suffixes: sum = summary, spr $=$ spring, aut $=$ autumn, win $=$ winter $)$

In respect of the stomach content analysis, red bandfish fed on pelagic planktonic organisms, is a zooplanktophagous species and especially its main food item group was identified as copepods (Tables 1-5).

\section{DISCUSSION}

There were hitherto only five studies conducted on the feeding habits of red bandfish, Cepola macrophthalma. Vives et al. (1959), studying this fish from Spanish waters (Ebro estuary), reported that the main food items were Sagitta spp., followed by copepods (especially Calanus spp., Centropages typicus, Clausocalanus spp., Ctenocalanus vanus, Pleuromamma spp., Scottocalanus persecans, Oncaea spp., and Corycaeus spp.), while amphipod and decapod larvae were found only sporadically. The stomachs of bandfish from Ebro estuary contained also deep-water plankton species. Other studies - conducted by Atkinson (1976) and Atkinson et al. (1977) in the Bristol Channel (12 $\mathrm{m}$ of depth) and covering one and 10 fish specimens, respectively - revealed that the dominant food items were copepods (Calanus helgolandicus, Centropages typicus, Temora longicornis, and Candacia armata). Few other food items, such as euphausiids, chaetognaths (Sagitta spp.), copepod larvae, and red bandfish eggs were found only sporadically. Regner (1977), studying C. macrophthalma in central Adriatic, identified copepod eggs, copepodids, and Oikopleura spp. larvae as the dominant food items of the red bandfish post-larvae. According to Stergiou (1993) the diet of bandfish from the bays of Euboikos and Pagassitikos (western Aegean Sea, Greece), consisted of copepods (60.4\%) and euphausiids (30.1\%). The above-mentioned author also noticed seasonal differences in the fish diet. In September the most abundant were: Clausocalanus spp., Acartia sp., and Temora stylifera; In December-Calanus helgolandicus, Eucalanus spp., and Clausocalanus spp.); in March-Calanus helgolandicus and Eucalanus spp.; while in June-euphausiids.

Čakelić (unpublished ${ }^{*}$ ) conducted a study on the diet of red bandfish from Adriatic Sea and reported that the dominant food item in summer were euphausiids, followed by copepods, whereas in all the remaining seasons the principal diet item were copepods.

The presently reported results on the stomach content of red bandfish were consistent with the results of the five research projects described above. The only major difference was that in the studies done by Vives et al. (1959), Stergiou (1993), and Čakelić (unpublished*) copepods were the second dominant food item, whereas in our study pelagic copepods were dominant in all seasons. We believe that the presently reported shift towards copepods might be a result of the presumed abundance of zooplankton off the Turkish coast. This would be consistent with the results of Stergiou (1993), who concluded that, red bandfish food preference changes according to the abundance of the plankton rather than the size of planktonic organisms. According to Vives et al. (1959) and Atkinson (1977) there was a relation between the composition of zooplankton found in the stomach contents of the red bandfish and the depth they inhabit.

The prey organisms found in the stomach contents of red bandfish well reflect the species composition present at respective depths inhabited/visited by this fish (Scotto di Carlo et al. 1984, Weikert and Trinkaus 1990, Sever unpublished $^{* *}$, Aker unpublished ${ }^{* * *}$ ). Stergiou (1993) reported that red bandfish hides and rests in the cavities made by it, but subsequently it feeds in the pelagic zone.

\footnotetext{
* Čakelić M. 2014. Sezonska prehrana i dužinsko-maseni odnos mačinca crvenog, Cepola macrophthalma (Linnaeus, 1758) na području južnog Jadrana. [Seasonal nutrition and length-weight relationship for red bandfish, Cepola macrophthalma (Linnaeus, 1758) in the southern Adriatic.] BSc Thesis. Dubrovnik University, Croatia. [In Croatian.] ** Sever T.M. 1997. Ege Denizi Pelajik Kopepod'larının Belirlenmesi ve Önemli Türlerinin Nitel ve Nicel Dağılımları. [Establishment of pelagic copepods and quantative and qualitative distributions of important copepod species in Aegean sea of Turkey.] PhD Thesis. Dokuz Eylül University, İzmir, Turkey. [In Turkish.]

*** Aker V. 2002. Türkiye'nin Orta Ege Karasuları Planktonik Kopepodlarının Mevsimsel Dağılımı. [Seasonal distribution of planktonic copepods in the Turkish coastal waters of the middle Aegean Sea.] PhD Thesis. Ege University. [In Turkish.]
} 
In our study, the copepods were the dominant group in the stomach content, but this group was represented by meroplanktonic and holoplanktonic organisms. This fact obviously showed that bandfish feed in the pelagic zone.

Prey items in the stomach contents represented different taxa, including also rarely consumed prey items, representing Isopoda, Amphipoda, Gastropoda, and Thaliacea. Copepods were the most important prey group of bandfish and they were dominant in terms of numbers and frequency in each season and stomach. Copepods were also reported as the dominant group in each season by zooplankton studies from various region of the Aegean Sea (Moraitou-Apostolopoulou 1972, 1976, 1985, Benli et al. 2001, Özel and Aker 2004, İșinibilir 2009, Sever unpublished*, Aker unpublished*). Exceptionally, cladocerans were dominant group along with copepods in a seasonal and horizontal sampling study by Özel and Aker (2004). Nonetheless, frequency of Cladocera was lower in our study. This fact may be explained that Cladocera species are more abundant in surface waters than they are in the feeding areas of red bandfish (MoraitouApostolopoulou and Kiortsis 1973).

Corycaeus typicus, Oncaea media, Acartia clausi, and Euterpina acutifrons were found frequently in both, oceanic and neritic regions in the Aegean Sea (Sever unpublished*). A study by Aker (unpublished*) from the Aegean Sea also reported that Centropages typicus, Oncaea media, Acartia clausi, Temora stylifera, Corycaeus typicus were dominant in all seasons, while Paracalanus parvus was a dominant species in the winter. The most dominant copepod species of our study were: Oncaea media, Corycaeus typicus, Acartia clausi, Clausocalanus arcuicornis, Centropages typicus, Ditrichocorycaeus brehmi, Temora stylifera, Paracalanus parvus, and Euterpina acutifrons with various numbers in each season.

None of the previously mentioned researchers, studying feeding habits of the red bandfish, observed how the prey composition of this fish changes along with its length. Our study seems to be first providing such data. We also managed to demonstrate that the red bandfish is a zooplanktophagous species. Even though the species lives on the bottom, it prefers to feed on pelagic organisms. This fact indicates ontogenetically based food preferences of the species.

\section{ACKNOWLEDGEMENT}

This study was supported by the Ege University Scientific Research Fund (Project No: 2005/SÜF/007).

\section{REFERENCES}

Atkinson R.J.A. 1976. Some preliminary field observations of the burrows of the red bandfish, Cepola rubescens L. Journal of Fish Biology 9 (2): 181-183. DOI: $10.1111 /$ j.1095-8649.1976.tb04671.X

Atkinson R.J.A., Pullin R.S.V., Dipper F.A. 1977. Studies on the red band fish, Cepola rubescens. Journal of Zoology (London) 182: 369-384.

DOI: $10.1111 /$ j.1469-7998.1977.tb03916.x
Bauchot M.-L. 1987. Poissons osseux. Pp. 891-1421. In: Fischer W., Bauchot M.-L., Schneider M. (eds.) Fiches FAO d'identification des espèces pour les besoins de la pêche. (Révision 1). Méditerranée et mer Noire. Zone de pêche 37. Vol. 2, Vertébrés. FAO, Rome.

Benli H.A., Tarkan A.N., Sever T.M. 2001. Comparison of the mesozooplankton composition the southwestern Black Sea, Sea of Marmara and eastern Aegean Sea. Turkish Journal of Marine Science 7 (3): 163-179.

Brodskii K.A. 1967. Calanoida of the far eastern seas and polar basin of the USSR. Keys to the Fauna of the USSR. Vol. 35. Israel Program for Scientific Translations, Jérusalem, Israel.

Dulčić J., Kokan B., Vrgoč N., Glamuzina B., Conides A.J., Skaramuca B. 2008. Age, growth and mortality of red bandfish, Cepola macrophthalma (L.) in the eastern Adriatic Sea (Croatian coast). Journal of Applied Ichthyology 24 (3): 351-353. DOI: $10.1111 /$ j.1439-0426.2007.01047.x

Düzbastılar F.O. 2014. Dip trolünden kaçan kurdele balığının (Cepola macrophthalma) ölüm oranlarının belirlenmesi. [Determining escape mortality of red bandfish (Cepola macrophthalma) escaping from bottom trawl.] Ege Journal of Fisheries and Aquatic Sciences 31 (2): 61-68. DOI: 10.12714/egejfas.2014.31.2.02 [In Turkish.]

Giacalone V.M., D’Anna G., Badalamenti F., Pipitone C. 2010. Weight-length relationships and condition factor trends for thirty-eight fish species in trawled and untrawled areas off the coast of northern Sicily (central Mediterranean Sea). Journal of Applied Ichthyology 26 (6): 954-957.

DOI: $10.1111 /$ j.1439-0426.2010.01491.x

Hyslop E.J. 1980. Stomach content analysis-A review of methods and their applications. Journal of Fish Biology 17 (4): 411-429.

DOI: $10.1111 /$ j.1095-8649.1980.tb02775.x

İşinibilir M. 2009. Summer mesozooplankton communities in the Turkish coastal waters of north Aegean Sea. Journal of FisheriesSciences.com 3 (3): 237-242. DOI: $10.3153 /$ jfscom.2009.029

Kaya M., Özaydın O., Benli H.A. 2001. Age and growth parameters of red bandfish (Cepola rubescens L., 1766) in İzmir Bay. Turkish Journal of Zoology 25 (2): 111-116.

Martín P., Sabatés A. 1991. Spatio-temporal distribution pattern of the red band-fish Cepola rubescens Linnaeus at different stages of its life cycle in the northwestern Mediterranean. Journal Fish Biology 39 (4): 549-557. DOI: $10.1111 /$ j.1095-8649.1991.tb04385.x

Moraitou-Apostolopoulou M. 1972. Occurrence and fluctuation of the pelagic copepods of the Aegean Sea with some notes on their ecology. Hellenic Oceanology and Limnology 11: 325-402.

Moraitou-Apostolopoulou M. 1976. Influence de la mer Noire sur la composition de la faune planctonique (Copépodes) de la mer Egée. Acta Adriatica 18 (16): 271-274.

* See footnote on page 222. 
Moraitou-Apostolopoulou M. 1985. The zooplankton communities of the eastern Mediterranean (Levantine Basin, Aegean Sea); Influence of man-made factors. Pp. 303-329. DOI: 10.1007/978-1-4899-2248-9_14 In: Moraitou-Apostolopoulou M., Kiortsis V. (eds.) Mediterranean Marine Ecosystems. Vol. 8. NATO Conference Series. Springer US, New York, NY, USA. DOI: $10.1007 / 978-1-4899-2248-9$

Moraitou-Apostolopoulou M., Kiortsis V. 1973. The cladocerans of the Aegean Sea Occurrence and seasonal variation. Marine Biology 20 (2): 137-143. DOI : 10.1007/BF00351451

Özel İ., Aker V. 2004. İzmir körfezi, tuzla önleri zooplanktonu. ["A study on the zooplankton of Çamaltı saltern front, İzmir Bay”.] Türk Sucul Yaşam Dergisi 2 (2): 160-167. [In Turkish.]

Pinkas L., Oliphant M.S., Iverson I.L.K. 1971. Food habits of albacore, bluefin tuna and bonito in Californian waters. Fish Bulletin 152: 1-105.

Regner S. 1977. On the feeding of Serranus hepatus (L.) and Cepola macrophthalma (L.) postlarvae in the central Adriatic. Rapports et procès-verbaux des réunions - Commission internationale pour l'exploration scientifique de la Mer Méditerranée 24: 87-88.

Rose M. 1933. Copépodes pélagiques. Faune de France. Vol. 26. Fédération Française des sociétés de sciences naturelles; office central de faunistique. Paul Lechevalier, Paris.

Scotto di Carlo B., Ianora A., Fresi E., Hure J. 1984. Vertical zonation patterns for Mediterranean copepods from the surface to $3000 \mathrm{~m}$ at a fixed station in the Tyrrhenian Sea. Journal of Plankton Research 6 (6): 1031-1056.

DOI: $10.1093 /$ plankt/6.6.1031

Stergiou K.I. 1993. Abundance-depth relationship, condition factor and adaptive value of zooplanktophagy for red bandfish, Cepola macrophthalma. Journal Fish Biology 42 (5): 645-660.

DOI: $10.1111 /$ j.1095-8649.1993.tb00374.x
Stergiou K.I. 1999. Intraspecific variations in size- and ageat-maturity for red bandfish, Cepola macrophthalma. Environmental Biology of Fishes 54 (2): 151-160. DOI: $10.1023 / A: 1007594719450$

Stergiou K.I., Economidis P., Sinis A. 1992. Age, growth and mortality of red bandfish, Cepola macrophthalma (L.), in the western Aegean Sea (Greece). Journal Fish Biology 40 (3): 395-418. DOI: $10.1111 /$ j.1095-8649.1992.tb02586.x

Stergiou K.I., Economidis P., Sinis A. 1996. Sex ratio, spawning season and size at maturity of red bandfish in the western Aegean Sea. Journal Fish Biology 49 (4): 561-572.

DOI: $10.1111 /$ j.1095-8649.1996.tb00054.x

Stergiou K.I., Papaconstantinou C. 1993. Natural mortality of red bandfish, Cepola macrophthalma (L.), in the Aegean Sea (Greece): Comparison of direct and indirect estimation methods. Fisheries Research 16 (4): 347-361. DOI: $10.1016 / 0165-7836(93) 90146-\mathrm{x}$

Tortonese E. 1986. Cepolidae. Pp. 810-811. In: Whitehead P.J.P., Bauchot M.-L., Hureau J.-C., Nielsen J., Tortonese E. (eds.) Fishes of the North-eastern Atlantic and the Mediterranean. Vol. II. UNESCO, Paris.

Vallisneri M., Piccinetti C., Tommasini S. 2006. Age, growth, and gonad organization in red bandfish (Cepola macrophthalma L., 1758) from the Adriatic Sea. Acta Adriatica 47 (2): 217-221.

Vives F., Suau P., Planas A. 1959. Sobre la biología de la cinta (Cepola rubescens L.). Investigación Pesquera 14: 3-23.

Washington H.G. 1984. Diversity, biotic and similarity indices: A review with special reference to aquatic ecosystems. Water Research 18 (6): 653-694. DOI: 10.1016/0043-1354(84)90164-7

Weikert H., Trinkaus S. 1990. Vertical mesozooplankton abundance and distribution in the deep eastern Mediterranean Sea SE of Crete. Journal of Plankton Research 12 (3): 601-628. DOI: $10.1093 /$ plankt/12.3.601

Received: 9 March 2016 Accepted: 2 September 2016 Published electronically: 30 September 2016 